\title{
Nucleoside $\mathbf{N}$-acylation with active derivatives of amino acids
}

\author{
Sergiy M. Yarmoluk*, Alexander M. Kostenko, Dmytro V. Kryvorotenko, \\ Igor Ya. Dubey \\ Institute of Molecular Biology and Genetics, National Academy of Sciences of the Ukraine \\ 150 Zabolotnogo str., 252143, Kyiv, Ukraine \\ 'Institute of Bioorganic Chemistry and Petrochemistry, National Academy of Sciences of the Ukraine \\ 1 Murmanska str., 253660, Kyiv, Ukraine
}

\begin{abstract}
Simple procedure for $N$-acylation of adenosine, guanosine and cytidine by active derivatives of amino acids is propased. Procedure is based on transient silyl protection of ribose hydroxy groups and consists of 3 steps: (a) silylation of nucleoside by trimethylchlorosilane, $(b)$ reaction of amino group of silylated nucleoside with chloroanhydride or active ester.of $N$-protected amino acid, $(c)$ desilylation of intermediate. The yields of $N$-aminoacylated nucleosides were about $40-90 \%$.
\end{abstract}

Introduction. Problems concerning the design of drug delivery forms for biologically active modified nucleosides are now under investigation in many laboratories, and a number of approaches has been developed [1]. Conjugates of nucleosides with amino acids and peptides are promising compounds from this point of view. O-aminoacylated nucleosides were used previously. 5'Aminoacyl derivatives of AZT ( $3^{\prime}$-azido- $2^{\prime}, 3^{\prime}$-dideoxythymidine) with Phe, Lys, Ser, lle, Glu were tested as the depot-forms for drug delivery. Their activity in cell cultures was similar to that of AZT itself [2]. The preparation of 5 -amino acid phosphoroamides of zidovidine, $3^{\prime}$-deoxy-2', $3^{\prime}$-didehydrothymidine and $3^{\prime}$-fluoro-3'-deoxythymidine allowed to increase their efficiency of selective inhibition of HIV viral replication [3].

We propose the use of exocyclic amino groups of nucleosides as possible alternative for their conjugation with amino acids and peptides via amide bond. Probably amino acid derivatives of nucleosides can be hydrolyzed after their penetration into the cell by intracellular enzymes being converted into corresponding free nucleosides. The reaction of unprotected nucleosides with $\mathrm{N}$-protected amino acids in the presence of DCC (dicyclohexylcarbodiimide) was studied before. Selective acylation of exocyclic amino functions was achieved only for cytidine. For $\mathrm{N}$-acylation of adenosine and guanosine, equimolar amounts of $\mathrm{N}$-phtaloylamino acids chloroanhydrides were used, but ribose hydroxy groups were acylated too, and the yields of $\mathrm{N}$ aminoacylnucleosides were low [4].

Here we describe a simple method for the selective $\mathrm{N}$-acylation of nucleosides with active derivatives of amino acids using a transient silyl protection strategy. Chloroanhydrides and active esters of amino acids were

\footnotetext{
"Correspondence address.

(C) S. M. YARMOLUK, A. M. KOSTENKO, D. V. KRYVOROTENKO, I. Y. DUBEY, 1996
} 
used as acylating reagent to obtain $\mathrm{N}$-aminoacylated nucleosides. With the use of active esters it was also possible to prepare under mild conditions nuclesides conjugates with peptides and some another compounds containing carboxy function which could not be easily obtained via chloroanhydrides.

Materials and Methods. Adenosine, guanosine and cytidine were purchased from «Biolar» (Latvia), amino acids and $\mathrm{N}$ (benzyloxycarbonyl)-amino acids from «Reanal» (Hungary), DCC and PFF (pentafluorophenol) from «Sigma» (USA), HOBt (1-hydroxybenzotriazol) was synthesized according to [5]. N-Pht (phtaloyl) amino acids and chloroanhydrides were prepared as described in [6]. Solvents and reagents were prepared as follows: Diox (1,4-dioxane) was refluxed with sodium for $12 \mathrm{hrs}$ and distilled; Py (pyridine) was distilled over $\mathrm{P}_{4} \mathrm{O}_{10}$, ninhydrine, and then refluxed over $\mathrm{CaH}_{2}$ for $2 \mathrm{hrs}$ and distilled; acetonitrile was distilled over $\mathrm{P}_{4} \mathrm{O}_{10} ; \mathrm{TMSCl}$ (trimethylchlorosilane) was distilled over $\mathrm{AlCl}_{3}$. The TLC was performed on Kieseigel $60 \mathrm{~F}_{254}$ plates ( $\ll$ Merck», Germany) using $n$-butanol:acetic acid:water (4:1:1) system. ${ }^{1} \mathrm{H}$ NMR spectra were recorded on Varian VXR-300 (75.4 MHz) NMR-spectrometer in DMSO-d6 using tetramethyl silane as internal standard.

Reverse phase HPLC was performed on Beckman «Gold System» using Ultraprep $\mathrm{C}_{18}(21 \times 1.5 \mathrm{~cm}$, «Beckman») column. A 0-30\% gradient of acetonitrile in $0.1 \mathrm{M}$ TEAB (triethylammonium bicarbonate) buffer ( $\mathrm{pH} 6.5$ ) with flow rate $4 \mathrm{ml} / \mathrm{min}$ was used throughout.

GENERAL PROCEDURE 1 (GP1). Nucleoside ( $5 \mathrm{mmol}$ ) was coevaporated with anhydrous $P y$ in vacuo, suspended in $50 \mathrm{ml}$ of the same solvent and $35 \mathrm{mmol}$ of TMSCl was added dropwise during $30 \mathrm{~min}$ with stirring. After $2 \mathrm{hrs}$ a solution of $\mathrm{N}$-phtaloylaminoacyl chloride $(7 \mathrm{mmol})$ in Py-Diox (4:1) was added dropwise, with stirring. After TLC showed the absence of starting nucleoside (in other case additional $3-5 \mathrm{mmol}$ of chloroanhydride were added), water $(10 \mathrm{ml})$ and $15 \mathrm{~min}$ later $5 \mathrm{ml}$ of concentrated aqueous ammonia were added to the reaction mixture. After $10 \mathrm{~min}$ solvents were removed in vacuo, the residue was treated with water and extracted with ethylacetate. Crystallization of desired product from water layer began immediately. If no, water layer was separated and evaporated in vacuo until crystallisation began. The crystals were filtered off, recrystallized from aqueous alcohol, and dried in vacuo over $\mathrm{P}_{4} \mathrm{O}_{10}$. Yields were $70-80 \%$.

GENERAL PROCEDURE 2 (GP2). N-protected amino acid $(7 \mathrm{mmol}$ ) and HOBt (or PFF) $(7 \mathrm{mmol}$ ) were coevaporated with dry Py, dissolved in $30 \mathrm{ml}$ of Py-acetonitrile (1:3) and 7,5 mmol of DCC were added with stirring. After $3 \mathrm{hrs}$ the reaction mixture was filtered from dicyclohexyl urea into the flask with silylated nucleoside (see GP1) $(5 \mathrm{mmol})$ and the course of reaction was monitored by TLC. Usually the reaction was completed in $1-3$ days. Products were isolated as described in GP1. Yields were $40-70 \%$.

$N^{2}-\left(\right.$ Phtaloylphenylalanyl)-guanosine (Pht-Phe-G) GP1; $R_{f} 0.67 ;{ }^{1} \mathrm{H}$ NMR $\delta 12.1$ (s, 1H, H1), 8.3 (s, 1H, H8), 7.8 (m, 4H, Pht), 7.1 (m, 5H, Phe), 5.8 (d, $\left.1 \mathrm{H}, \mathrm{H}^{\prime}\right), 5.3$ (t, $1 \mathrm{H}, \mathrm{CH}$ Phe), 4.3 (t, 1H, H2'), 4.1 (s, 1H, H3'), 3.8 (m, $\left.1 \mathrm{H}, \mathrm{H} 4^{\prime}\right)$; m. p. $217-219$; yield $73 \%$.

$N^{6}$-( $N$-Carbobenzoxyphenylalanyl)-adenosine (Z-Phe-A); GP2 with HOBt; $\mathrm{R}_{\mathrm{f}} 0.70 ;{ }^{1} \mathrm{H}$ NMR $\delta 8.8-8.7(2 \mathrm{~s}, 2 \mathrm{H}, \mathrm{H} 2+\mathrm{H} 8), 7.5-7.1$ (m, 10H, 2Phe), 6.0 (d, $\left.1 \mathrm{H}, \mathrm{Hl}^{\prime}\right)$; m. p. 104-106; yield $41 \%$.

$N^{2}-\left(N\right.$-Phtaloyl-E-aminohexyl)-guanosine (Pht-Ahe-G): GP1; $\mathrm{R}_{\mathrm{f}} 0.65 ;{ }^{1} \mathrm{H}$ NMR $\delta 12.1$ (s, 1H, H1), 11.7 (s, 1H, NHCO), 8.3 (s, 1H, H8), 7.9-7.7 (m, $4 \mathrm{H}, \mathrm{Pht}), 5.8\left(\mathrm{~d}, 1 \mathrm{H}, \mathrm{H}^{\prime}\right), 4.4\left(\mathrm{t}, 1 \mathrm{H}, \mathrm{H} 2^{\prime}\right), 4.1\left(\mathrm{t}, 1 \mathrm{H}, \mathrm{H}^{\prime}\right), 3.9(\mathrm{~m}, 1 \mathrm{H}$, $\left.\mathrm{H} 4^{\prime}\right), 3.7-3.5$ (m, 4H, 2H5'+2H Ahe), 2.5-2.3 (m, 2H, Ahe), 1.7-1.5 (m, 4H, Acp), 1.4-1.2 (t, 2H, Ahe); m. p. 196-198; yield $86 \%$. $N^{2}-\left(N\right.$-Phtaloylvalyl)-guanosine (Pht-Val-G): GP1; $\mathrm{R}_{\mathrm{f}} 0.65 ;{ }^{1} \mathrm{H}$ NMR $\delta$ 12.1-11.9 (br. s, 2H, Hl, NHCO), 8.3 (s, 1H, H8), 7.9-7.7 (m, 4H, Pht), 
5.7 (d, $\left.1 \mathrm{H}, \mathrm{H} 1^{\prime}\right), 4.7$ (d, 1H, CH Val), $4.3\left(\mathrm{~m}, 1 \mathrm{H}, \mathrm{H}^{\prime}\right), 4.1\left(\mathrm{~m}, 1 \mathrm{H}, \mathrm{H}^{\prime}\right)$, 3.8 (d, $\left.\left.1 \mathrm{H}, \mathrm{H}^{\prime}\right), 3.7-3.4\left(\mathrm{~m}, 2 \mathrm{H}, \mathrm{H5}^{\prime}\right), 2.7 \mathrm{(m}, 1 \mathrm{H}, \mathrm{CH} \mathrm{Val}\right), 1.0(\mathrm{~d}, 3 \mathrm{H}$, $\left.\mathrm{CH}_{3}\right), 0.8$ (d, 3H, $\left.\mathrm{CH}_{3}\right)$; m. p. 184-186; yield $90 \%$.

$N^{2}-\left(N\right.$-Carbobenzoxyglycyl)-guanosine (Z-Gly-G): GP2 with HOBt; $\mathbf{R}_{\mathrm{f}} 0.51$;

${ }^{1} \mathrm{H}$ NMR $\delta 11.8$ (br. s, 2H, H1, NHCO), $8.3(\mathrm{~s}, 1 \mathrm{H}, \mathrm{H} 8), 7.3(\mathrm{~m}, 5 \mathrm{H}, \mathrm{Ph})$, $5.8\left(\mathrm{~d}, 1 \mathrm{H}, \mathrm{H}^{\prime}\right), 5.0\left(\mathrm{~s}, 2 \mathrm{H}, \mathrm{CH}_{2}\right), 4.4\left(\mathrm{t}, 1 \mathrm{H}, \mathrm{H} 2^{\prime}\right), 4.1\left(\mathrm{t}, 1 \mathrm{H}, \mathrm{H}^{\prime}\right), 4.0-3.8$ (m, 3H, $\mathrm{H3}^{\prime}, \mathrm{CH}_{2}$ (Gly)), 3.7-3.5 (m, 2H, H5'); m. p. 173-175; yield $67 \%$. $N^{4}-(N$-Carbobenzoxyglycylglycyl)-cytidine (Z-Gly-Gly-C): GP2 with OBt; $\mathrm{R}_{\mathrm{f}} 0.55 ;{ }^{1} \mathrm{H}$ NMR $\delta 8.5$ (d, $\left.1 \mathrm{H}, \mathrm{H6}\right), 7.4(\mathrm{~s}, 5 \mathrm{H}, \mathrm{Ph}), 7.3$ (d, $\left.1 \mathrm{H}, \mathrm{H} 5\right), 5.8(\mathrm{~d}$, $\left.1 \mathrm{H}, \mathrm{H} 1^{\prime}\right), 5.0\left(\mathrm{~s}, 2 \mathrm{H}, \mathrm{CH}_{2}\right), 4.0-3.8\left(\mathrm{~m}, 7 \mathrm{H}, 2 \mathrm{CH}_{2}(\mathrm{Gly}), \mathrm{H} 2^{\prime}, \mathrm{H}^{\prime}, \mathrm{H}^{\prime}\right)$, 3.7 (m, 2H, H5'); m. p. 138-140; yield $47 \%$.

$N^{2}-\left(2,4-\right.$ dinitrophenylacetyl)-guanosine (DNPAc-G): GP2 with $\mathrm{HOBt} ; \mathrm{R}_{\mathrm{f}}$ $0.50 ;{ }^{1} \mathrm{H}$ NMR $\delta 12.2(\mathrm{~s}, 1 \mathrm{H}, \mathrm{H} 1), 11.8(\mathrm{~s}, 1 \mathrm{H}, \mathrm{NHCO}), 8.8,8.6,7.9(\mathrm{~ms}, 3 \mathrm{H}$, $\mathrm{Ar}), 8.3(\mathrm{~s}, 1 \mathrm{H}, \mathrm{H} 8), 5.8\left(\mathrm{~d}, 1 \mathrm{H}, \mathrm{H}^{\prime}\right), 4.5-4.3\left(\mathrm{~m}, 3 \mathrm{H}, \mathrm{CH}_{2}, \mathrm{H}^{\prime}\right), 4.1(\mathrm{t}$, $\left.\left.1 \mathrm{H}, \mathrm{H}^{\prime}\right), 3.9 \mathrm{~m}, 1 \mathrm{H}, \mathrm{H}^{\prime}\right), 3.7-3.5\left(\mathrm{~m}, 2 \mathrm{H}, \mathrm{H}^{\prime}\right)$; m. p. 183-185; yield $80 \%$;

Determination of $N$-amionoacylation yields in model experiments. Model $\mathrm{N}$-aminoacylation reaction with various active esters were carried out according to GP2 with $0.1 \mathrm{mmol}$ of nucleosides. The course of reaction was monitored by TLC. After a certain reactions time (see the Table) the mixture was treated with water and aqueous ammonia, and an aliquot of the resulting solution was analyzed by HPLC to determine the reaction yield.

Results and discussion. Since $\mathrm{N}$-aminoacyl derivatives of nucleosides are compounds of considerable biological interest, we have developed a simple and efficient method for their preparation based on the transient protection strategy described by Jones et al. [7]. The idea of this strategy is to make the acylation reaction $\mathrm{N}$-specific by prior protection of free hydroxyl functions of ribose residue with labile silyl groups. Our approach is illustrated by the following scheme:

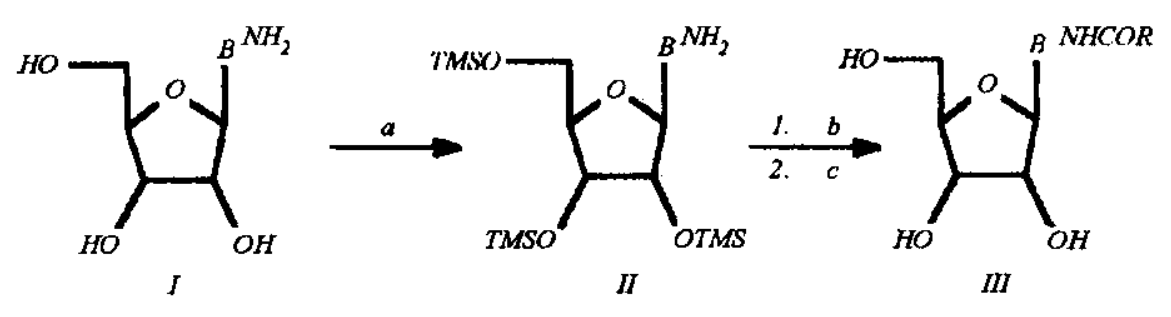

a $-\mathrm{Me}_{3} \mathrm{SiCl} / \mathrm{Py} ;$ b $-\mathrm{RCOX} ; \mathrm{c}-\mathrm{NH}_{4} \mathrm{OH} / \mathrm{H}_{2} \mathrm{O}$

$\mathrm{B}-$ heterocyclic base (adenine, guanine or cytosine)

$\mathbf{R}$ - N-protected amino acid residue

$\mathrm{X}-\mathrm{Cl}$, -PFF, -ONSu, -OBt

After the silylation of starting ribonucleoside I with TMSCl in Py it was treated with active derivative of $\mathrm{N}$-protected amino acid, namely chloroanhydride or active ester. Selective $\mathrm{N}$-acylation of nucleoside was achieved followed by the hydrolysis of silyl O-protecting groups to give $\mathrm{N}$-aminoacyl derivative III.

Chloroanhydrides are widely used for the preparation of nucleosides 
$\mathrm{N}$-protected with common acyl groups like benzoyl and isobutyryl by transient protection method. We employed chloroanhydrides of $\mathrm{N}$-protected amino acids as aminoacylating reagents. The reaction was as efficient as nucleoside $\mathrm{N}$-acylation with usual chloroanhydrides. Typically, when acyl chlorides of $\mathrm{N}$-phtaloylamino acids were used, the one-flask reaction was completed in 2-4 hrs (GP1). Usually $\mathrm{N}$-aminoacylated nucleosides could be easily separated from the reaction mixture by crystallization, and after the recrystallization from aqueous alcohol the desired products were obtained in a high yield $(70-90 \%)$. Nevertheless, the use of aminoacyl chlorides is far from being a general way for nucleoside $\mathrm{N}$-aminoacylation, as it has some important limitations: 1) with the exception of N-Pht protected, aminoacyl chlorides are usually hardly available; 2) many amino acids cannot be converted into chloroanhydrides even with phtaloyl N-protecting group; 3) formation of chloroanhydrides of optically active amino acids leads to their racemization.

To overcome these problems, we decided to use the active esters of amino acids as mild $\mathrm{N}$-acylating reagents. The use of some active esters for nucleoside $\mathrm{N}$-protection was described previously. 4-Nitrophenylbenzoate and pentachlorophenylbenzoate [9] were used to obtain N-benzoylcytidine. Hydroxybenzotriazolyl ester of phenoxyacetic acid prepared from phenoxyacetyl chloride and $\mathrm{HOBt}$ was used to protect guanosine amino function [8 ]. Almost any compound containing a carboxy group can be converted into corresponding active ester to be used as acylating reagent. We have studied the reactivity of PFF, ONSu and HOBt active esters of amino acids and peptides towards exocyclic amino groups of adenosine, guanosine and cytidine. Active esters were prepared using well-established procedures of peptide synthesis, e. g. by treating the mixture of protected amino acid and corresponding hydroxy component with DCC. To evaluate the reactivity of active esters, a series of model experiments were carried out without the isolation of $\mathrm{N}$-aminoacylated nucleosides. The course of reaction was monitored by TLC, and the yields were determined by HPLC. The results are presented in the Table.

Reactivity of active esters in model reactions with nucleosides

\begin{tabular}{|c|c|c|c|c|}
\hline $\begin{array}{c}\text { Amino acid or } \\
\text { peptide }\end{array}$ & Active ester & Nucleoside & Time, hrs & $\begin{array}{l}\text { Vieid of aminoacyl } \\
\text { nucleoside. } \%\end{array}$ \\
\hline \multirow[t]{7}{*}{ Z-Gly-Gly } & OBt & $\mathrm{C}$ & 12 & 88 \\
\hline & & A & 48 & 61 \\
\hline & & $\mathbf{G}$ & 72 & 76 \\
\hline & PFF & C & 24 & 71 \\
\hline & & A & 72 & 31 \\
\hline & & $\mathbf{G}$ & 72 & No reaction \\
\hline & ONSu & C & 72 & 28 \\
\hline \multirow[t]{3}{*}{ Z-Phe } & OBt & A & 72 & 87 \\
\hline & PFF & $\mathbf{A}$ & 72 & 29 \\
\hline & ONSu & A & 72 & No reaction \\
\hline \multirow[t]{2}{*}{ Z-Gly } & $\mathrm{OBt}$ & $\mathbf{G}$ & 48 & 72 \\
\hline & PFF & G & 72 & No reaction \\
\hline \multirow[t]{2}{*}{$T r^{1}-$ Gly } & PFF & C & 48 & 78 \\
\hline & ONSu & C & 72 & 21 \\
\hline \multirow[t]{3}{*}{$\mathrm{NPs}^{2}-\mathrm{Ahe}^{3}$} & $\mathrm{OBt}$ & C & 12 & 92 \\
\hline & PFF & C & 12 & 67 \\
\hline & ONSu & C & 72 & 14 \\
\hline
\end{tabular}

${ }^{1}$ Triphenylmethyl; ${ }^{2}$-nitrophenylsulfenyl; ${ }^{3} 6$-aminohexanoic acid. 
$\mathrm{N}$-acylation efficiency depended strongly on the nature of active ester and nucleoside. The best yields were observed for the reaction of cytidine with $\mathrm{OBt}$ and PFF esters (67-92\%). Adenosine and guanosine amino groups as less nucleophilic than cytidine $\mathrm{NH}_{2}$ need more active acylating reagents, and they were acylated with OBt esters with $61-87 \%$ yields, whereas PFF esters were not enough active to react with $A$ and $G$ efficiently. At the same time, ONSu esters did not react with $A$ and $G$ at all and only slowly with $C$. The results obtained are in full agreement with known facts that the basicity of nucleoside amino groups increases from $G$ to $C$, and the reactivity of active esters towards $\mathrm{NH}_{2}$ groups increases in the order ONSu < PFF < OBt [8]. The experimental data show that $\mathrm{OBt}$ esters are the most efficient reagents suitable for $\mathrm{N}$-aminoacylation of all nucleosides and could be recommended as reagents of choice for the preparative use. Pentafluorophenyl esters are quite active for cytidine $\mathrm{N}$-acylation, and ONSu esters cannot be considered as useful for the preparation of $\mathrm{N}$-aminoacylated nucleosides by the proposed method.

So, only OBt and PFF active esters of amino acids were used further in this work for the preparative synthesis of $\mathrm{N}$-aminoacyl nucleoside derivatives. The general procedure for their use (GP2) was quite similar to that utilising chloroanhydrides. The solution of freshly prepared active ester was added to the silylated nucleoside. $\mathrm{N}$-aminoacylation with active esters was slower than with chloroanhydrides and required $1-3$ days, depending on the nucleoside and the active ester used. After the acylation reaction was completed labile trimethylsilyl protecting groups were removed by short treatment with diluted ammonia. The desired products were crystallized from the reaction mixture after its evaporation and extraction and then recrystallized from aqueous alcohol to give corresponding $\mathrm{N}$-aminoacyl ribonucleosides with the yields of $40-80 \%$. The structure of nucleoside derivatives was confirmed by ${ }^{1} \mathrm{H}$ NMR. The average yields seem to be somewhat higher for the procedure GP1, although the direct comparison of two procedures was not carried out. But the obvious advantage of active esters is that they are mild reagents of general use (see above). It should be noted that the procedure GP2 can be used not only for any amino acid, but also for the conjugation of nucleosides with peptides and other classes of compounds which are labile or contain a carboxy group that cannot be easily converted into haloanhydro function. We were able to prepare successfully the conjugates of nucleosides with Gly-Gly using the $\mathrm{OBt}$ ester of $\mathrm{N}$-protected dipeptide; the yield of Z-Gly-Gly-C was $47 \%$.

In addition, the use of active esters can be also preferable when the corresponding chloroanhydride is highly reactive. For example, DNPAc chloride is too active electrophilic reagent to be used directly for nucleoside acylation. At the same time, N-(DNPAc)-guanosine was prepared in a high yield $(80 \%)$ by the mild procedure GP2. Finally, it would be also interesting to study the possible use of active esters of amino acids for direct selective $\mathrm{N}$-acylation of nucleosides without any protection of ribose residue, as they are known to be highly $\mathrm{N}$-specific reagents in peptide chemistry. It would simplify the method considerably.

Thus, we have reported a convenient procedure for the preparation of ribonucleoside $\mathrm{N}$-aminoacyl derivatives ( of course, this method can be used also for deoxyribonucleosides). Conjugates of this class could be able to release free nucleoside within the cell being the depot-forms for their delivery. The attachment of amino acids and peptides to biologically active modified nucleosides would be therefore especially interesting, and derivatization of azapyrimidine nucleosides by the proposed approach is now studied in our laboratory.

The project is supported by National Academy of Sciences of Ukraine. 
С. М. Ярмолюк, О. М. Костенко, Д. В. Криворотенко, І. Я. Дубей

$\mathrm{N}$-ацилювання нуклеозидів активними похідними амінокислот

Резгоме

Запропоновано просту нетодиху для $N$-ацилювання аденозину, гуазину $і$ цитидіну активними похідними амінокислот. У процедурі використано тимнасовый захист сильними залииками гідрокситьних груп рибози, який здійснюеться в три етапи: силюванням нуклеозидів триметилхлорсиланом (а); ацилюванням аміногруп силільованих нуклеозидів хлорангідридами або активньми ефірами N-захищених амінокислот (6) і десилюванням ацильованого нуклеозиду (в). Виходи $N$-ацильованих нуклеозидів складають $40 \rightarrow 90 \%$.

С. Н. Ярмолюк, А. Н. Костенко, Д. В. Криворотенко, И. Я. Дубей

$\mathrm{N}$-ацилирование нуклеозидов активными производными аминокислот

Резюме

Предложена простая методика для $N$-ацилирования аденозина, гуанозина и цитидина активньми производными аминокислот. В процедуре использована еременная зачита силильными остатками гидроксильньх групп рибозы, которую осуществляли в три этапа: силилованием нуклеозидов триметилхлорсиланом ( $a$ ); ачилированием аминогрупл силированных нуклеозидов хлорангидридами или актиеньми әфирами $N$-замищенных аминокислот( 6 ) и десилированием ацилированного нуклеозида ( в). Выходы $N$-ацилированных нуклеозидов составляют $40-90 \%$.

\section{REFERENCES}

1. Krayevsky A. A., Watanabe $K$. A. Modified nucleosides as anti-AIDS drugs: current status and perspectives.-M.: Bioinform, 1993.-212 p.

2. Aggraval S. K., Gogu S. R., Randan S. R. S., Agrawal N. C. Synthesis and biological evaluation of prodrugs of zidovudine // J. Med. Chem.-1990.-33.-P. 1505-1510.

3. Abraham T.W., Wagner C. R. A phosphoroamidite-based synthesis of phosphoroamidate amino acid diesters of antiviral nucleosides // Nucleosides and Nucleotides.-1994.-13, N 9.P. $1891-1903$.

4. Shabarova Z. A., Bogdanov A. A. Chemistry of nucleic acids and their components.-M.: Khimia, 1978.-P. 88.- (Russian).

5. Nietzky R., Braunschweyg E. Ueber die Einwirkung von Alkalien auf Orthonitrophenylhydrazin // Chem. Ber. - 1894.-27.-P. 3381-3384.

6. Greenstein J. P. Winitz $M$. Chemistry of amino acids.-New York; London, 1961.P. 465-467.

7. Ti G. S., Gaffney B. L, Jones R. A. Transient protection: efficient one - flask synthesis of protected deoxynucleosides // J. Amer. Chem. Soc.-1982.-104.-P. 1316-1319.

8. Chaix C., Duplaa A. M., Molko D., Teoule R. Solid phase synthesis of the 5'-half of the initiator t-RNA from B.Subtilis // Nucl. Acids Res.-1989._17.-P. 7381-7393.

9. Gait M. J., Matthes H.W. D., Singh.M. et al. Synthesis of oligodeoxyribonucleotides by a continuous flow phosphotriester method on a kieselguhr/polyamide support // Chemical and enzymatic synthesis of gene fragments: a laboratory manual / Eds. H. G. Gassen, A. Lang.Berlin: Verlag Chemie, 1982.-P. 1-42. 